\title{
Cuadernos de Gibraltar Gibraltar Reports
}

Revista Académica sobre la Controversia de Gibraltar Academic Journal about the Gibraltar Dispute 


\title{
THE GIBRALTAR CRISIS AND THE MEASURES, OPTIONS AND STRATEGIES OPEN TO SPAIN
}

\begin{abstract}
I. THE CURRENT NEGOTIATING DEADLOCK AND CRISIS - II. SPAIN'S STRATEGIC OPTIONS - III. THE MEASURES PROPOSED BY SPAIN IN AUGUST 2013 - IV. DOES SPAIN REALLY WANT TO REGAIN GIBRALTAR? - V. CONCLUSION.
\end{abstract}

The diplomatic crisis that broke out in July and August of 2013 between Spain and the UK due to the dispute of fishing rights and environmental protection in the waters surrounding the Rock has prompted the announcement by the Spanish government of a parcel of measures to be taken against Gibraltar. The escalation with the UK has led to protests over more stringent controls at the frontier and to the firmly expressed British support for the Gibraltarian authorities, coinciding with the arrival of several Royal Navy ships en route to an exercise in the Mediterranean.

This paper looks at a number of issues concerning the validity of some of the Spanish government's measures and with Spain's current strategy in relation to this historical controversy. It first analyses the context in which the measures are to be adopted in order to subsequently consider them in light of the strategic options open to Spain in its dispute over Gibraltar.

\section{THE CURRENT NEGOTIATING DEADLOCK AND CRISIS}

The point of departure is the historically very worrying deadlock on Gibraltar, since there are at present no valid means of dialogue on the controversy between the UK and Spain, or for including Gibraltar in cross-border cooperation talks. With the change in both governments in 2010-11, the institutional channels were formally blocked in 2012: the Trilateral Dialogue Forum was deactivated when Spain demanded its conversion into a four-sided entity and the UK rejected changing what was agreed bilaterally in October 2004.2 Additionally, in 2012

\footnotetext{
${ }^{1}$ Professor of Public International Law, Jean Monnet Chair of EU Law, University of Cádiz. Trabajo publicado como Análisis del Real Instituto Elcano, ARI 32/2013 (Translated from Spanish), 30.09.2013 (http://www. realinstitutoelcano.org/) y realizado en el marco del Proyecto de Investigación de I+D "Cuestiones territoriales y Cooperación transfronteriza en el Área del Estrecho”, DER2012-34577 (subprograma JURI) del Plan Nacional de I+D+i 2013-2015, financiado por el Ministerio de Economía y Competitividad y los fondos FEDER de la UE (IP: Dr. A. del Valle Gálvez).

${ }^{2}$ See the analysis by Alejandro del Valle Gálvez (2012), “Gibraltar, de foro tripartito a cuatripartito: entre la
} 
FIGURE 1. Site of Community Importance (SCI) in the waters surrounding the Rock

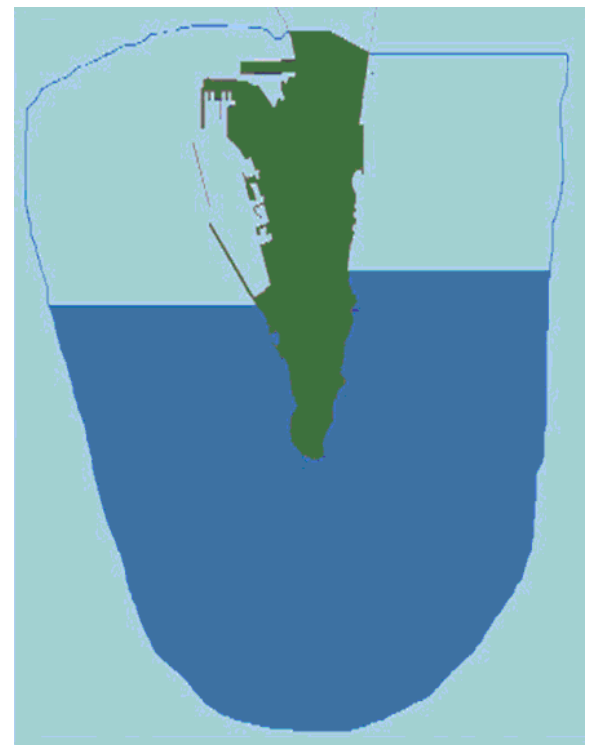

The area in blue is known as the Southern Waters of Gibraltar, recognised in 2006 as a Site of Community Importance (SCI) by the European Commission. The British SCI does not cover the entirety of the British Gibraltar Territorial Waters.

Source: Gibraltar Nature News, nr 112 12, 2006; I. GonZález García \& A. del Valle Gálvez (Eds.), Gibraltar y el foro tripartito de diálogo, Ed. Dykinson, Madrid, 2009, p. 541.

the UK again opposed reactivating the bilateral Brussels Process of 1984, since it demanded Gibraltar's acquiescence for doing so.

The absence of dialogue has led to many incidents in the Bay of Gibraltar -or Algeciras, as it is known in Spanish- related to the Spanish fishing fleet and to the presence in the waters surrounding the Rock -British Gibraltar Territorial Waters- of vessels of the Royal Navy, the Spanish Navy, the Civil Guard and the Royal Gibraltar Police. Especially during 2012 and 2013, Gibraltar suspended the application of the informal agreement of 1999 with the Spanish fishermen's guilds ${ }^{3}$-the previous official accord, signed in 1998 by the Foreign Minister Abel Matutes and the Foreign Secretary Robin Cook, was never put into practice-, ${ }^{4}$

cooperación transfronteriza y la soberanía”, ARI nr 21/2012, Elcano Royal Institute, 23/III/2012, < http://www. realinstitutoelcano.org/wps/portal/rielcano/contenido?WCM_GLOBAL_CONTEXT=/elcano/elcano_es/ zonas_es/europa/ari21-2012>.

3 <http://www.publications.parliament.uk/pa/cm199899/cmselect/cmfaff/366/9042006.htm>.

${ }^{4}$ <http://www.parliament.the-stationery-office.co.uk./pa/cm199899/cmselect/cmfaff/366/9042004.htm>. 
FIGURE 2. Special Conservation Zone (Zona Especial de Conservación or ZEC) in the waters surrounding the Rock

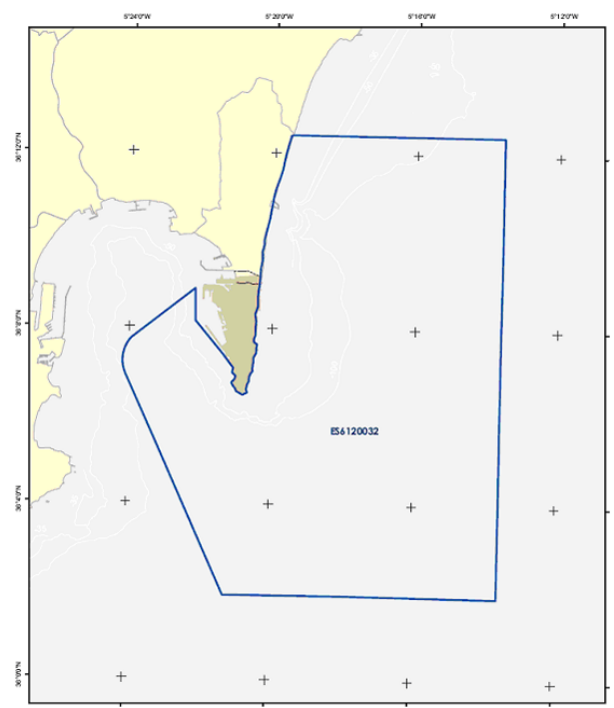

Royal Decree 1620/2012, of 30 November, declared the Site of Community Importance ES6 12032 Estrecho Oriental of the Red Natura 2000's Mediterranean biogeographical region a Special Conservation Zone (Zona Especial de Conservación or ZEC), approving the relevant conservation regulations.

Source: BOE, nr 289, de 1/XII/2012; I. GonzÁLEZ GARCía \& M. Acosta SÁnCheZ, "La difícil aplicación de la estrategia marina europea y la protección del medio marino en la Bahía de Algeciras/Gibraltar", Revista Electrónica de Estudios Internacionales, nr 25, 2013.

invoking environmental reasons and leading to the banning and cessation of fishing -with subsequent meetings and reports- and then to Gibraltar's unilateral decision to create an artificial reef with 70 blocks of concrete in July 2013, which in practice put paid to continuing any fishing activities in the area. The underlying issue was clearly the jurisdiction over the waters and their environmental protection, with two partially overlapping Sites of Community Importance -one British and another Spanish- (see Figure 1 and 2).

At first the Spanish government requested the continuation of the informal accord of 1999, but it has now adopted a number of measures in view of the fait accompli of the fishing ban. Since it is important to bear in mind the Government's political objectives, it is necessary to look at the measures adopted from a general perspective to identify the specific object they are pursuing and to consider them in the context of Spain's realistic options in the Gibraltar controversy. 


\section{SPAIN'S STRATEGIC OPTIONS}

It is usually said that Spain's strategy on Gibraltar has been erratic and there have certainly been significant non-consensual jumps in focus depending on each government in office-for instance, both in the creation and suppression of the Tripartie Trilateral Dialogue Forum-. Nevertheless, democratic Spain has been constant on a certain number of issues, such as the rapprochement with the Gibraltarians and negotiating with the UK under the UN's decolonisation mandate. But even these policies are now being questioned or are showing signs of exhaustion.

In such a scenario, what are Spain's options? In the current position, its range of strategic possibilities are actually very limited ${ }^{5}$ :

(1) Reactivating the Brussels Process and the Dialogue Forum, or establishing some other negotiating format. The UN's mandate to negotiate decolonisation had, in the first decade of the 21st century, been reasonably managed by Spain with the blessings of the General Assembly: bilateral negotiations on sovereignty via the Brussels Process, the Trilateral Dialogue Forum for cross-border cooperation (with purely local affairs dealt with by the joint committee of Gibraltar and the Spanish municipalities in the Gibraltar area -Comisión Mixta Gibraltar-Mancomunidad de Municipios-). Nevertheless, both channels are currently blocked, because the UK is opposed to restarting the Brussels Process while Spain refuses to take part in the Dialogue Forum. Furthermore, the UN's demand for decolonisation is currently rejected by the UK. Not only do the British and Gibraltarian narratives disregard the fact that the internationally accepted status of Gibraltar is that of a non-autonomous territory -one of the few that are still pending decolonisation and about which year after year the UN insists that self-determination requires negotiations between the UK and Spain in order to restore the latter's territorial integrity- but they specifically consider such a doctrine obsolete and inapplicable since the people of Gibraltar already decided on their self-determination when they drafted the 1966 with the 2006 Constitution.

(2) The judicial option. Resorting to a court of law -essentially the International Court of Justice at The Hague (ICJ) - is highly unlikely, since the ICJ cannot automatically deal with a case such as this, which would require a specific Spanish-British agreement. Furthermore, it is extremely risky for Spain as the best-case scenario of a ruling in its favour would not

\footnotetext{
${ }^{5}$ See, for instance, Alejandro del Valle Gálvez (2013), "España y la cuestión de Gibraltar a los 300 años del Tratado de Utrecht”, ARI nr 23/2013, Elcano Royal Institute, 20/VI/2013, <http://www.realinstitutoelcano.org/wps/ portal/rielcano/contenido?WCM_GLOBAL_CONTEXT=/elcano/elcano_es/zonas_es/ari23-2013-gonzalezgalvez-espana-gibraltar-300-anos-tratado-utrecht>.
} 
resolve the controversy -but only reinforces Spain's negotiating position-, while a worstcase scenario of a ruling against it would be catastrophic for the position it has maintained with UN support over the past 50 years, giving legal and practical cover to a new European micro-State under British protection and under the Union Jack. In any case, seeking British agreement to submitting the case to the ICJ remains a possibility -although unlikely- but would require a very broad consensus as it would leave Spain's centuries-old claim in the hands of an international tribunal.

(3) An imaginative negotiation for an ad hoc solution for Gibraltar. Under the Brussels Process or otherwise, a tailor-made solution seeking a permanent and stable international status for Gibraltar is a good option for Spain, although it requires reconciling three very different but vital interests: the UK's military needs, Gibraltarian approval and the recovery in whatever form of Spanish sovereignty. But there could be a distinctive formula for the unique Gibraltarian case: a model inspired by Andorra or Monaco or the status of an international city associated to the EU and closely linked to the surrounding Spanish municipalities. This option is likely to be the one to provide the best results for Spain's desire for a definitive solution, despite the significant internal (nationalist independence movements) and external (the permanent Moroccan claims over Ceuta and Melilla) risks, which would therefore require a broadly-based and historical national consensus.

(4) A low-profile reclamation based on UN doctrine and the restrictive application of the Treaty of Utrecht. This is the traditional option of hindering life in Gibraltar, seeking all ways of limiting its advantages and preventing it from abusing its privileged position. It is not a solution but a way of exerting pressure on the UK and Gibraltar with a view to engaging in negotiations and reaching accords, although in the absence of any format or conduit for dialogue (as at present) can only lead to a greater deadlock and the risk of escalation. Conflicts have been especially acute since 2009 as regards the maritime areas around the Rock, since there has been no desire to reach a modus vivendi or a practical agreement to exert provisional jurisdictional authority in Gibraltar's waters.

\section{THE MEASURES PROPOSED BY SPAIN IN AUGUST 2013}

An initial problem when considering the Spanish government's measures is that they have merely been announced in the media but not officially adopted. They are in accordance with the traditional option ( $\mathrm{nr} 4$ ) of limiting illegal or abusive action by Gibraltar. They are coutermeasures or retaliatory measures whose aim is to return to the statu quo ante in terms of fishing rights and environmental regulation, and that were announced in reaction to the 
sinking of concrete blocks by Gibraltar in Spain's traditional fishing grounds.

Specifically, the media declarations of Spain's Minister of Foreign Affairs and Prime Minister and newspaper reports ${ }^{6}$ suggest that the following measures are being considered:

- Filing a complaint on the dumping of concrete blocks before the environmental Prosecutor and the European Commission.

- Implementing a plan against tax fraud and specifically inspecting the 6,700 Gibraltarians resident in Spain.

- Reinforcing inspections at the frontier in order to prevent smuggling, money laundering and illicit trafficking.

- Modifying the gaming laws in order to ensure that Spanish servers are used by Internet gaming companies and online casinos in Gibraltar.

- Annulling certain accords signed under the Trilateral Forum, particularly the Córdoba Declaration $^{8}$ relative to air traffic, closing Spanish airspace and restricting flights from Gibraltar.

- Preventing the entry to Gibraltar of concrete and other construction materials.

- Studying the possibility of establishing a $€ 50$ levy on entry and exit from Gibraltar, to be redistributed to the fishermen affected by the prohibition to operate in their traditional fishing grounds.

- In this context, measures have also been announced to counter the bunkering business in the waters around the Rock, which are largely part of the Spanish Special Conservation Zone (Zona Especial de Conservación or ZEC) as established by Royal Decree 1620/2012 of 30 November, which declared as a ZEC the Site of Community Importance Estrecho Oriental (see Figure 2).

Similarly, procedures have been initiated to implement an order from the Ministry of Agriculture to subsidise the fishing fleet in Algeciras and La Línea. ${ }^{10}$

Along with this, and directly related to the Spanish reaction, controls have been reinforced

\footnotetext{
${ }^{6}$ Interview with Foreign Minister García-Margallo in ABC, 5/VIII/2013, <http://www.abc.es/espana/20130804/ abci-garcia-margallo-entrevista-201308032026.html>, <http://www.abc.es/espana/20130803/abci-freno-provoca ciones-gibraltar-201308031313.html>, and declarations of the Spanish Prime Minister, 9/VIII/2013, <http:// www.lamoncloa.gob.es/Presidente/Actividades/ActividadesNacionales/2013/090813RajoyMallorca.htm>.

7 <http://www.europasur.es/article/gibraltar/1575200/espana/protesta/ante/la/ue/por/lanzamiento/hormigon /mar.html>.

8 Alejandro del Valle Gálvez (2006), "Los acuerdos del Foro de Dialogo sobre Gibraltar: la apuesta por la normalización”, ARI nr 107/2006, Elcano Royal Institute, <http://www.realinstitutoelcano.org/ analisis/1060/1060_ValleGalvez_Gibraltar.pdf $>$.

${ }^{9}<$ http://www.boe.es/diario_boe/txt.php?id=BOE-A-2012-14698>.

$10 \quad<$ http://www.lamoncloa.gob.es/ServiciosdePrensa/NotasPrensa/MinisterioAgriculturaAlimentacionMedio Ambiente/2013/120813AyudasPesca.htm>.
} 
at the frontier as an external European border. This prompted a conversation between David Cameron and Mariano Rajoy ${ }^{11}$, followed by a talk between the Minister of Foreign Affairs and the Foreign Secretary who agreed, according to Spain, on the creation of ad hoc working groups. ${ }^{12}$ For its part, the UK announced that it would study initiating unprecedented measures against the border controls. ${ }^{13}$

As for the frontier, although it is not considered as such by Spain, it does view it as a border crossing where individuals and merchandises are checked. There is a presumption in favour of the lawfulness of Spain's action, since it is a European external land border of the Schengen area, to which the UK does not belong, while Gibraltar is furthermore not a member of the customs union. Hence, the burden of proof is on the party claiming that an illegality has occurred. Naturally, everyone in the area knows from years ago that political crises have an immediate effect on how slow the border crossing is. Nevertheless, the problem of traffic congestion at the Gibraltar border has already been the subject in previous years of many complaints to the Commission, none of which has been submitted to the Court of Justice of the European Union. Of course, the delays exasperate both the Gibraltarians and the other inhabitants of the area and create a sense of vulnerability in Gibraltar, so it is no surprise that the checks - described as 'inhuman'- will be brought before the relevant international bodies. Despite the strong presumption of legality in favour of Spain, since the checks are in conformity with the Schengen Border $\operatorname{Code}^{14}$ (with Spain claiming they are in accordance with the principles of randomness, proportionality and non-discrimination), the extraordinary increase in the delays and their synchrony with the parcel of measures adopted against Gibraltar can detract from any claim to objectivity for the border checks imposed since the crisis broke out.

On the other hand, there is a strong presumption against the legality of the proposed $€ 50$ levy. In the absence of a full legal analysis of both the measure and its justification -since it is Spain's responsibility to argue its lawfulness-, the border levy does appear to be problematic. In principle it cannot rely directly on the restrictions specified in the Treaty of Utrecht, since in my opinion only the first and last paragraphs of Art. X are clearly in force, so that the second paragraph's limitations on communications are no longer valid and, if they were, they

\footnotetext{
${ }^{11}$ <http://www.lamoncloa.gob.es/Presidente/Actividades/ActividadesInternacionales/2013/070813rajoycameron .htm $>$.

12 Communiqué 144 of the Spanish Ministry of Foreign Affairs and Cooperation, 7/VIII/2013, <http:// www.exteriores.gob.es/Portal/es/SalaDePrensa/Comunicados/Paginas/2013_COMUNICADOS/20130807_ COMUNICADO144.aspx $>$.

${ }^{13}<$ http://www.elmundo.es/elmundo/2013/08/12/espana/1376305796.html>.

14 <http://eur-lex.europa.eu/LexUriServ/LexUriServ.do?uri=CELEX:32006R0562:ES:HTML>.
} 
would be contrary to the EU Treaty, which has precedence over earlier treaties. Actually, as a border levy or tax, there are several aspects of the measure that make its application doubtful: (a) its motivation due to, or coinciding with, a problem or crisis of a political nature -in this case, the explicit purpose of directing the amount collected to the fishermen is an admission of its political motivation-; (b) its proportionality is doubtful unless it is directly linked to technical external cross-border controls and the ensuing delays and problems; (c) it is very likely that a $€ 50$ levy for entry plus another $€ 50$ exit tax $-€ 100$ for crossing a frontier in a country where the minimum wage is $€ 645$ - will have a deterrent effect on the free movement of persons and citizens in the EU; and (d), finally, a similar 'decongestion' levy (of $€ 5$ per vehicle) adopted in 2010 by the authorities of La Línea de la Concepción was already declared illegal by the Attorney General and suspended by a court in Algeciras.

But, regardless of this controversial prospective levy, the main drawback of these measures is that they do not seek the resolve the controversy -like all those adopted under category (4) above, aimed at restricting Gibraltarian abuses- and, because they are divorced from Spain's main vindicatory arsenal -the UN doctrine on decolonisation- can easily be denounced as mere political retaliation. Certainly, the immediate objective is clearly to make a show of force and not accept Gibraltar's encroachments on Spain's rights, in addition to highlighting the former's vulnerability and dependence on the latter -as has been abundantly made clear-. The objective of returning to the previous situation as regards fishing rights, before the unilateral sinking of concrete blocks by Gibraltar, also reaffirms Spanish sovereignty over the disputed waters.

Nevertheless, some of the measures announced, such as revising or nullifying the soft law agreements adopted by the Trilateral Forum are a radical break in seeking a rapprochement with the Gibraltarian population, which has been the traditional approach adopted by Spain since the transition to democracy.

There is a further immediate objective, or negotiating strategy, involving cross-border cooperation, which focuses on somehow achieving one of the initial goals on the government of Mariano Rajoy regarding Gibraltar: instate a four-sided dialogue. The idea of creating foursided ad hoc groups -which, according to the media, was accepted in writing by the Foreign Secretary, William Hague, on 14 April 2012, although the Foreign Office actually referred to exploring an ad hoc dialogue that includes Gibraltar- $-{ }^{15}$ could in itself justify the Spanish plan if a permanent four-sided channel of communication is established. Nevertheless, the idea of

\footnotetext{
${ }_{15}$ FCO Press Release, 7/VIII/2013, <https://www.gov.uk/government/news/foreign-secretary-calls-spanishforeign-minister-garcia-margallo $>$.
} 
creating four-sided working groups would appear to be subject to limitations and in the best of cases -assuming the Gibraltarian government accepts, when it has already announced its rejection $-{ }^{16}$ will simply allow the Junta de Andalucía and the Mancomunidad de Municipios del Campo de Gibraltar to participate on an equal footing with Gibraltar, Spain and the UK to deal with specific issues. In any case, both the Junta and the Mancomunidad were already permanently integrated the dialogue forum -in the Joint Commission coordinated by the forum-. The gain would therefore be achieving in a different way the conversion of the Trilateral Dialogue Forum into a four-sided concern, as the government wanted as a matter of principle in January 2012, although under a new format (a new 'local cooperation mechanism', as reflected by the different focus expressed in the latest decision about Gibraltar adopted by the UN General Assembly on 18 December 2012). ${ }^{17}$

Of course, if Spain manages to establish four-sided working groups or a local cooperation mechanism this in itself would be an achievement and would at least allow it to enjoy an institutional channel for debate, negotiation and the adoption of agreements. Having some sort of structure, even if only for cross-border cooperation -without which diplomatic crises are inevitable- has proved to be vital, even if less effective than the Trilateral Forum: the latter is currently ruled out mainly because it gives symbolical recognition to Gibraltar as a direct and equal partner on cross-border issues. Nonetheless, the Forum did provide a permanent format with pre-established formulas and an open agenda to deal on a daily basis with both the British and the Gibraltarians and to negotiate and agree with them on affairs relating directly or indirectly to Gibraltar.

In summary, the parcel of measures announced by Spain could help it achieve a number of political objectives, showing firmness before Gibraltar's unilateral acts and, in the best of cases, the ad hoc four-sided working groups on fishing and the environment would serve as channels for cross-border dialogue. However, these goals do not seek the resolution of the dispute and call into question the policy of normalising relations with the Gibraltarian population that has been pursued by Spain since the democratic transition. Meanwhile, the UK remains at a remove from any direct confrontation, thereby maintain the status quo. Certain measures, if adopted -such as the border congestion levy-could have unwanted legal or political consequences.

Nonetheless, it has subsequently emerged that there has been a complete change of perspective, with Spain's parcel of measures being complemented by other options and

16 Gibraltar Press Release 585/2013, 7/VIII/2013, <https://www.gibraltar.gov.gi/images/stories/PDF/ pressoffice/pressreleases/2013/585-2013.pdf>.

17 <http://daccess-dds-ny.un.org/doc/UNDOC/LTD/N12/542/89/PDF/N1254289.pdf?OpenElement>. 
strategies planned for Gibraltar. ${ }^{18}$ Apparently, the idea, pending confirmation, is to engage in a general strategic offensive to take the Gibraltar issue to international forums such as the EU and the UN -at both the General Assembly and the Security Council-. Specifically, there is a plan to present a non-consensus draft resolution on Gibraltar to be voted on in the General Assembly, associating the Gibraltar issue with the Argentine claim on the Falkland Islands, joining in a common cause with Argentina to submit the matter to the Security Council. A further consideration is to present a case before an international tribunal.

Should the strategic plan be confirmed, then the parcel of border measures proposed in August might have to be viewed differently, as a circumstantial show of force within a general strategy that combines all of Spain's real options, as explained above.

\section{DOES SPAIN REALLY WANT TO REGAIN GIBRALTAR?}

Spain's current government has on several occasions expressed its claim to Gibraltar, at different times during its term in office. If in January 2012 its formal request to London was to reactivate the bilateral Brussels Process and reconvert the Dialogue Forum in a four-sided forum with the Mancomunidad de Municipios del Campo -although it has been rejected by the UK-, in 2013 there has been a whole array of measures in response to Gibraltar's unilateral action, which at first had appeared to be limited to returning to the fishing agreement of 1999 and substituting the Forum by a local cooperation mechanism, establishing new foursided ad hoc working groups that include the Junta de Andalucia. But in the wake of the fishing and environmental crisis, Spain subsequently engaged in an all-out offensive whose aim is to take the Gibraltar case and decolonisation to international forums, with a final recourse to international tribunals. Spain's action has emerged piecemeal, as events unfolded, so that no global strategy has yet been released in a fully detailed fashion. This perhaps explains why in the international media the question of Gibraltar has been considered merely an excuse to cover up the political crisis and corruption scandals rocking the domestic scene.

If the Spanish government has really decided to embark on a wide-ranging international offensive to regain sovereignty over Gibraltar, it would be convenient to consider the following issues before engaging in an all-out struggle:

- First, and although it might seem obvious, it must be accepted that 'regaining' Gibraltar means 'negotiating' a solution sooner or later with the UK; similarly, at some point, sooner or later, it must be accepted that it will be necessary -ex ante, during or ex post- to

${ }_{18}$ El País, 11/VIII/2013, <http://politica.elpais.com/politica/2013/08/10/actualidad/1376162592_175442. html>. 
negotiate with or count on the approval of the Gibraltarian government, whether after an agreement in the framework of the UN or following a ruling from an international court. This requires determining whether there is actually a genuine desire to regain Gibraltar whatever the consequences involved, based on a national consensus, the necessary constancy and the commitment to maintaining Spain's traditional lines of action: rapprochement with the Gibraltarians and dialogue with the UK under the UN's decolonisation mandate. It is therefore essential to have clear and precise medium and long-term objectives. Is it to re-start the Brussels Process? In that case, starting judicial proceedings that may be of very uncertain success is not the same as reinforcing the UN's decolonisation doctrine -which year after year has supported Spain since 1964 in order to force the UK to re-open bilateral talks. And, should this be the objective, what will be the aim of the conversation? Co-sovereignty? Integration into Spain as an autonomous region or province? Or a specific international solution for Gibraltar to replace the Treaty of Utrecht with Gibraltarian approval?

Furthermore, assimilating Gibraltar to the issue of the Falkland Islands is a political expedient that may be justified by the similarity of the UN decolonisation doctrines involved, but its limitations and consequences should be carefully considered. Spain's judicial position is far sounder than Argentina's as it is based on the Treaty of Utrecht and is in the framework of the EU and NATO, and on not having resorted to aggression during the period of the UN. But a common front objectively means introducing a third issue and a third State into the Gibraltarian equation, which could structurally distort Spain's position and subject it to legal and political eventualities beyond its control.

- Secondly, if the aim is to regain Gibraltar, then it is important to consider involving the Spanish Parliament in the debate on the British military base, which is the main conundrum -or one of the main ones- in the dispute. If Gibraltar's population has accepted the risks involved in having military facilities, the population in the neighbouring Campo de Gibraltar -and even in other parts of Spain- has not done so. Hence, the deep-seated connivance between Spain and the UK regarding the air force, naval and intelligence installations in Gibraltar and Spain's traditional silence on the matter should be subjected to debate in Parliament, since the British military bases - surrounded by Spanish waters- have never had Spanish consent as regards neither their presence, size, function, risks, emergency situations or evacuation plans in the Bay of Algeciras. The Spanish public must be informed about issues such as the docking and repair facilities for nuclear submarines, the type of British nuclear missiles in transit or stopping over in the Bay of Algeciras, the Royal Air Force's ammunition depots at the airport beside the frontier and the object and services provided by the data, signal 
and intelligence installations on the Rock. If a solution to the dispute is to be found, British military and strategic privileges must not be maintained at the expense of the security of the Spanish public.

- Third, if a solution to Gibraltar is sought through recourse to a tribunal or by direct negotiations with the UK, I believe there are formulas that would make it possible to limit its effects on other issues concerning Spain. However, it is highly unlikely for an international solution to Gibraltar not to have repercussions on the other side of the Straits. Of course, Spain's cities, islands and islets or rocks in Africa have never been considered cases subject to decolonisation by the UN and are not on its List of Non-Self-Governing Territories, in which Gibraltar is included. In any case, it must be accepted that a solution for Gibraltar is likely to be transposed to a certain degree to the cases of Ceuta and Melilla, although Moroccan foreign policy has not raised the comparison for some decades. But if a solution is found, it will inevitably affect the two cities due to the political and geographical similarities. Whether it is thought that a solution for Gibraltar is considered inapplicable to the case or that it might be strategically convenient in the long-term to consider the similarities, from the very beginning it must be borne in mind that it will be necessary to have an appropriate response and action plan ready.

\section{CONCLUSION}

The crisis with Gibraltar in July-August 2013 as a result of Spain's reaction to Gibraltar's unilateral action in disputed waters could be just the prelude to more bitter episodes. The parcel of measures announced by Spain -but not yet confirmed- has certain debatable aspects and is underpinned by a policy of showing firmness and limiting any abuses by Gibraltar. Nevertheless, some of the measures might be counterproductive to the aim of establishing four-sided negotiations of cross-border issues, since they imply putting an end to a policy of rapprochement with the Gibraltarian population. In any case, in the current crisis, Spain and the UK are best served by not upsetting their important common interests and by avoiding an escalation, reducing tension and even seeking an accord over some form of dialogue.

The measures announced appear to be part of a Spanish all-out offensive to take the dispute to international forums and tribunals, employing all the strategic options Spain has to hand. Despite not yet having further details about the objectives and phases involved in Spain's strategy, it is clear that the difficult starting point must contend with the British government's unequivocal support for Gibraltar and with the deterioration in Spain's recent policies towards the Rock (the population factor -normalising coexistence- and negotiating 
the UN's decolonisation mandate with the UK).

Nevertheless, the 2013 crisis could have a highly positive outcome if it helps to clarify Spain's internal position over Gibraltar and for the country to engage in a wide-ranging debate and generate a consensus over the strategic option to be followed over the coming years. Spain's claim to Gibraltar is one of the country's identity markers and a matter of national dignity. It is therefore worthwhile to ponder and reflect on the issue which to the Spanish mind is a national symbol and much more than just a singular rocky promontory on a bay in southern Spain. Spain can, of course, continue with a low-profile reclamation, with sporadic crisis of a greater or lesser intensity, while running the risk of an external event (such as the UK's exit from the EU or a change of tack in the UN's position on territories pending decolonisation, for instance) taking over the initiative and dictating Spain's policy. But the truth is that -with sufficient courage and a real political determination and consensus in Spainviable international solutions can be found to turn around an unhappy historical dispute and a serious everyday problem into a splendid opportunity for mutual understanding, economic development and permanent cooperation with both the UK and Gibraltar. 


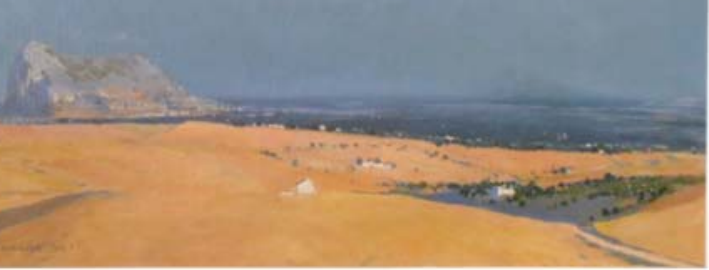

\section{Cuadernos de Gibraltar Gibraltar Reports \#01 | 2015}

Sumario - Enero / Diciembre 2015

Table of Contents - January / December 2015

EDITORIAL

Presentación de la revista.

ESTUDIOS

Antonio REMIRO BROTÓNS, "Gibraltar".

PARTE I - EL TRATADO DE UTRECHT (1713-2013)

Ángel J. SÁEZ RODRÍGUEZ , Gibraltar en 1704.

José Ramón REMACHA TEJADA, La Paz de Utrecht.

Paz ANDRÉS SÁENZ DE SANTA MARIAA, Gibraltar y el derecho de la descolonización.

Alejandro del VALLE GÁLVEZ, España y la cuestión de Gibraltar, a los $\mathbf{3 0 0}$ años del Tratado de Utrecth.

Jesús VERDÚ BAEZA, Las aguas de Gibraltar, el Tratado de Utrecht y el Derecho Internacional del Mar.

PARTE II - LA CRISIS DE GIBRALTAR (2013-2015)

Alejandro del VALLE GÁLVEZ, The Gibraltar crisis and the measures, options and strategies open to Spain.

Inmaculada GONZÁLEZ GARCIA, La pesca y el medio ambiente en las aguas de Gibraltar: la necesaria cooperación hispano-británica en el marco de la Unión Europea.

Miguel ACOSTA SÁNCHEZ, Incidentes hispano-británicos en las aguas de la Bahía de Algeciras / Gibraltar (2009-2014): ¿Qué soluciones?

ÁGORA

Daniel FEETHAM, La cuestión de Gibraltar: una perspectiva personal del líder de la oposición de Gibraltar.

Dominique SEARLE, The San Roque Talk.

DOCUMENTACIÓN

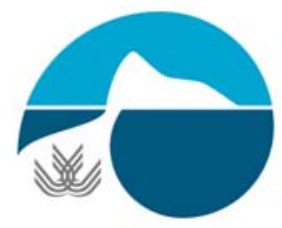

